\title{
NEW SOCIAL WORLD: THE GREAT POWER OF THE NETWORK
}

1. Komissarov, Sergey N.

2. Vasilyev, Nikolay A.*

1. Institute of Sociology of the Russian Academy of Sciences, Federal Research Sociological Center of the Russian Academy of Sciences, Moscow, Russia.

2. Master of Sociology at the Manchester University, Senior Researcher of the Sociocultural and Media Communications Research Sector of the Institute of Sociology of the Russian Academy of Sciences of the Federal Research Sociological Center of the Russian Academy of Sciences, Moscow, Russia. Corresponding author(nikolay.a.vasilyev@gmail.com)

\section{COPYRIGHT NOTICE:}

(C) 2021 by authors. Licensee ERUDITUS. This article is an open access article distributed under the terms and conditions of the Creative Commons Attribution (CC BY) license (https://creativecommons.org/licenses/by/4.0/).

\section{CITE THIS PAPER:}

Komissarov, Sergey N.; Vasilyev, Nikolay A. (2021). "New Social World: The Great Power of the Network" Journal of Social Sciences: Transformations \& Transitions (JOSSTT) 1(02):08. DOI: https://doi.org/10.52459/josstt1281221

\begin{abstract}
At the early beginning of the 21st century, it was impossible to imagine how fast the Internet would develop. It was also not obvious that the worldwide network would actually become available in all parts of the planet, and the network itself would become the basis for the birth and development of new global products - social networks, communications, and services. According to the International Telecommunication Union, the Internet and new digital products along twenty years have almost completely absorbed the population of developed countries (87\%) and are growing rapidly in developing countries $(47 \%)^{1}$. The affordable cost of communication for the majority of the population together with free communication services create the basis for the emergence of not only new products but also a constant increase in the number of digital services, which quite recently could only be obtained offline. Together with large digital government services, commercial networks, communicators, and services are creating a new social structure capable of independent machine learning and development. The work aims to show that much faster than it was supposed new digital products will intertwine with each other, forming a new social platform, which is called a New Social World. The analysis of sociological works on this topic together with an analysis of practical research on the Internet and new digital products confirms this assumption. Despite strict user agreements, global online monitoring, constant online control and full access to the data of each user, more and more people become users of social networks and services, and most social network users become loyal users of other new products and services, easily switching on digital consumption and consumption of real products and services provided online. The new social reality, generated by the powerful interweaving of the world's digital products and services will forever change the sociocultural and media world. An urgent and constant study of this phenomenon is necessary since the ways of its further development are unpredictable both in relation to the existence of traditional, social, national identification and with the existence of traditional state institutions and states.
\end{abstract}

\section{KEYWORDS}

New social world (NSW), Digital Capitalism, Worldwide Network, Social Networks \& Services, Surveillance Capitalism, Sociocultural \& Media Communications.

\footnotetext{
1 The International Telecommunication Union (ITU) is the United Nations' specialized agency for information and communication technologies ICTs. Founded in 1865 to facilitate international connectivity in communications networks, allocates global radio spectrum and satellite orbits, develops the technical standards that ensure networks and technologies seamlessly interconnect, and strives to improve access to ICTs to underserved communities worldwide. ITU is committed to connecting all the world's people - wherever they live and whatever their means. Available at: https://www.itu.int/ru/about/Pages/default.aspx
} 


\section{INTRODUCTION}

The first two decades of the XXI century are not only a period of qualitative and quantitative growth of scientific and technical discoveries. During this period humanity transitioned to a new level of social relations, traditional forms of human communication turned into virtual, cross-border forms quickly and voluntarily with a high level of self-mystification ${ }^{2}$. Traditional media have melted into hybrid forms of electronic communications and have actually merged with social networks, services, and communicators into one organically interacting world. New social space is changing with great speed under the influence of more and more new configurations of interhuman relations (Sztompka, 2017: 381-389) and the constant growth of technical capabilities immediately become a part of the process that accelerates the development of new types of interaction between participants in the new social space: consumers, users, friends, followers and all other members of the new social space.

The new virtual social space will expand, constantly absorb new parts of the former traditional real world and replace them with virtual counterparts. There are traditional socio-cultural groups that carefully guard their religious attitudes and spiritual values, but the new social world pushes these groups to the periphery of public attention and leaves them far behind new generations which feel like a duck to water in the new social space. And the more obvious this process is, the more acute is the question of where humanity is heading from the point of the content characteristics of spiritual development, whether it will be good for civilization to abandon traditional sociocultural, moral, and national attitudes, how the new social world will affect the development and self-manifestation of the individual.

Actually, the new virtual sociocultural and media communication paradigm discards unnecessary centuries-old social and individual life-meaning attitudes and creates a person of a new social world - "homo novi socialis mundi". There is no online-offline border for a typical user's mind in the new social world. There is the new virtual-real world an ordinary user, friend, follower perceives as a real living space. The conversion from the old traditional world to the new social world is occurring rapidly. Back in the early 2000s, scientists noted that the usage of the Internet is not very common among Russians (Delitsyn, 2010). In those days, 70\% of Russians aged from 16 to 65 (Petukhov, Barash, 2012: 111) did not have access to the Internet. The situation was similar in Europe. In twenty years $30 \%$ of the Russian population over the age of 12 constantly access the Internet and are registered in several social networks simultaneously. Russia has over 90 million registered users. This means that the level of Internet penetration in Russia is more than $90 \%$, the coverage of the network exceeds $90 \%$ (Mediascope, 2020). There are similar indicators in Europe, the USA, Southeast Asia, including

\footnotetext{
${ }^{2}$ Most of the users create their own "images" - they show on the network not themselves, real ones, but what they would like to see themselves as "advanced", "interesting", "sports", constantly traveling, etc. Users in the networks do not show disadvantages. There are very few real people in the networks as they are in everyday life. Women especially mystify themselves, often exhibiting only processed photos made with Photoshop.

${ }^{3}$ According to the installation study of the WEB-Index project, in February-November 2020, Internet penetration in Russia among the younger population (up to 44 years old) in 2020 exceeded 90\%, and among the youngest Russians (12-24 years old) approached 100\%.
} 
China. In general, the number of users of social networks in the world has already exceeded 17 billion accounts (Hootsuite, 2021). Only one of them - Facebook - in 2020 stepped over the mark of 3 billion users.

The New social world (Vasiliev, Komissarov, 2021) unites the new types of social, cultural, and media communications, including social networks, messengers, video conferencing programs, search resources, other online communicators, music and other thematic services, free online games in mobile and desktop ${ }^{4}$ and other entertainment facilities 5 .

It is a system of relationships and interactions between people, concepts and meanings, values and tastes, covering the entire real human world, all types of human activity, all social groups, which creates a new consciousness and human behavior based on strict laws and rules imposed by social networks. It is a constantly evolving social-organizational organism capable of regular introspection, having unlimited possibilities for comprehensive monitoring of users up to predictive analysis of their future behavior. NSW has online information about any user, user group and forms an absolute and reliable portrait of any user or user group based on high-precision mathematical models. NSW knows everything about each user, not only due to the information from the user but also due to the information about the user from other sources interacting in the NSW.

This is a new world in which a self-sufficient and comfortable environment has appeared for human existence and it does not require a human's real appearance and physical presence outside the home. The purpose of the study is to fix and define, perhaps, the most serious, global, and very rapid changes in the life of human society, which completely change not only the lifestyle of most people in different countries, but also change society itself beyond recognition.

\section{METHODOLOGICAL ASPECTS}

New social communications have long attracted the attention of researchers from different countries. A significant number of sociological materials that have appeared recently are descriptive. Social networks and services are viewed through the prism of statistics and marketing indicators (Sergeeva, 2021). Many authors of articles on social networks and services are often involved in describing their volumetric and quantitative characteristics, content, users, and user groups (Voronkin, 2014) and are ready to analyze and draw conclusions about the global prospects for the development of social media, intertwined with other social

\footnotetext{
${ }^{4}$ Mobile is a term for all mobile devices with Internet access. Desktop - a term for non-portable or rarely portable devices that have Internet access, usually desktop computers.

${ }^{5}$ Entertainment is not only entertainment content, it is an entertainment world in which the development, production, delivery and promotion of entertainment content to consumers takes place, primarily in video, photo, audio, texts, as well as in game format. The entertainment world is home to hundreds of streaming services, including YouTube and Telegram channels. The entertainment world today exists and is intertwined online and offline, most often in the form of various entertainment activities, including games, quizzes, shows, quests, etc.
} 
services and entertainment into a powerful supranational system of new social relations, in which the interaction of both individual and collective members of society completely moves online and does not require real human presence at work, school, etc.

In the European and American segment, you can find a lot of sociological articles about the negative impact of networks on the health of adolescents who overuse social networks or articles showing the negative impact of networks on the educational process of high school students. Many articles describe how networks completely control users. With deep respect for the sociological materials of R. Bailey, P. Purkayasha, and other respected and famous sociologists, it is worth noting that they are mostly focused on describing the global control by large international capital over the users of social networks (Bailey, Purkayasha, 2014). The direction of society's movement to the area of total control is well known since the time of J. Orwell (Orwell, 2016). It is only one of the elements of the new global social system, while the power and speed of control itself have increased and can be called now "total online control".

Undoubtedly, the new social world has full real-time control of all users. Evaluating sociological works of global importance, I would like to highlight "Surveillance Capitalism" by Sh. Zuboff. Surveillance capitalism has two main elements: the continuous collection of user data and the forecasting of user behavior (Zuboff, 2019: 240-267). These elements are also present in the concept of the New social world, but this is again only part of the new social system. The constant collection of data in the NSW has reached such a level when even a separate temporary page, a written and immediately deleted post, or a deleted "unsuccessful" photo remains in the database forever. This is "total online monitoring". Predicting user behavior is also not a new approach in sociology, predictive analysis of users and their actions has been carried out for a very long time, and now forecasting has simply reached its highest level - machine learning and recommendation services are a clear demonstration of this analysis in relation to each user; social networks and services already know more about users than the users know themselves (Morozov, 2019).

This is no longer just digital capitalism or its Schumpeter's mutations; it is not a new form of capitalism if the class theory is used. This is the global social space with its own virtual attitudes and laws absorbing different elements of all levels of the social-class structure. There is a need to emphasize the importance of a global approach to global phenomena, although the study of its individual elements is also very important. It can be assumed that sociology as a science will fall into the abyss between the existing and the surrounding reality without systemic research and analysis of the development of global socio-cultural and media communication changes.

The methodological basis of this topic is the sociocultural analysis of the changes that are taking place in the field of media communications, increasingly determining the course of development of all spheres of society, primarily in its spiritual and value dimension. There is an attempt to systematically consider the sociocultural transformations taking place under the influence of new forms of human communications. It is unlikely that the methodology for studying the new information and communication reality can be considered 
established. There is the contour outline of the most significant trends, which are changing thanks to the new technological discoveries, market and manipulation mechanisms, and an exponential increase in the number of people involved in the global social network of users which directly affects the quality of social, economic, cultural and demographic development of the modern society (Lokosov, 2020).

If earlier the Internet and nascent social networks were only an insignificant part of social and public life and used precisely as convenient services for quick communication or for quickly finding the necessary information, today social networks and services have reached such a technical and technological level when their influence on society has become inclusive. The user of new social media is so deeply immersed in a new social shell that it becomes almost impossible to get out of it. The user of the new social world receives practically everything in the new social space, from highly specialized training courses to the broadest possibilities of entertainment.

The unprecedented dynamics of these changes and the complexity of covering all new empirical facts, which reveal the sociocultural meaning of what is happening, makes it especially relevant to designate the empirical base of any analytics. It is worth noting that the deep immersion of users in a new social shell has its confirmation in terms of methods of reaching an audience. The traditional methodological techniques have been replaced by the CAWI method (computer-assisted web interviewing) and are being actively developed.

Together with telephone interviewing (CATI), electronic web interviewing has become the main method of obtaining sociological data during the pandemic. In relation to this article, such a base was compiled by CAWI research by the Research Center of the Association of Communication Agencies of Russia (ACAR), the Russian Association of Marketing Services and the Interactive Advertising Bureau (IAB Russia), analytical media data of the company MediaScope, statistical data of Rosstat, information and analytical data of Hootsuite, as well as data provided by the social networks itselves (Facebook, VKontakte, TikTok, Twitter, Instagram, YouTube, etc.), social (Google, Yandex, Mail, Rambler ) and educational (LinkedIn) platforms, social services and messengers (Telegram, WhatsApp, Viber), music, film and video services (Apple TV, Netflix, etc.), as well as open data from the Wikipedia encyclopedia, etc.

\section{RESULTS}

From a specialized computer network, the Internet "in a short time acquired the features of a social system" (Silaeva, 2008: 101-107) and now constitutes "a new social morphology (structure) of societies" (Vladimirova, 2011: 123). In the first twenty years of the new millennium, the types of communications have moved to a new technological and technical level, which is not comparable in terms of the reach of the audience and the depth of impact on it with any traditional communications. Not only the form and quality of communications have changed, but the speed of communications has also changed, especially the speed of 
transmission of electronic messages. The speed has increased several thousand times in comparison with the early Twentieth Century. The highest speed of communication is one of the definitions of the new information and cultural reality and largely predetermines the development of the New Social World (NSW). The study of NSW attracts the attention of representatives of various sciences and requires special methods (Bataeva, 2011).

The new social system entered the life of society with great speed, daily adding not only the new followers but also the new services that previously existed only in the old traditional system. The potential of the NSW allows talking about the creation of a world society with a unified management system. These are not only the most powerful social platforms (Facebook, Odnoklassniki, VKontakte, My World, TikTok, Twitter, Instagram, YouTube, etc.), but also developed social services and messengers (Telegram, WhatsApp, Viber, etc.), music services (Apple Music, Spotify, etc.) and movie and video services (Apple TV, Netflix, etc.), including electronic postal services and search engines (Google, Yandex, Mail, Rambler, etc.), online payment systems (PayPal, Apple Pay, Sber, etc.), marketplaces and online stores (Wildberries, Ozon, Lamoda, Yandex. Market, Goods, Aliexpress, Leroy Merlin, eBay, etc.), online food delivery, electronic pharmacies, systematized databases and electronic encyclopedias (Wikipedia, etc.) as well as educational and business platforms (LinkedIn) and other resources combined into separate ecosystems that provide the user with the opportunity to get the maximum online services. Social networks and services have reached such a level that they are able to influence all types of human life regardless of gender, age, marital and social status (Efimova, Zyuban, 2016). Globality is the main factor in the communication changes (Ponarina, 2011).

For the first time in the history of mankind, the forms and types of transmission and reception of global informational resources with friendly functions for maintenance and operation are not geographically localized and are generally accessible. Now a full-fledged modern life is not only connected with the Internet but is immersed in a new global online system. First of all, this applies to young people born after 1995, who, overwhelmingly, cannot imagine life without the Internet and social networks. According to the latest data from the Nielsen company, $98 \%$ of young age groups constantly, on a daily basis, spend their time in social networks having several accounts and navigating through them online. The absolute majority of young people are already in the NSW.

We are observing a worldwide trend of people moving, especially young generations, young consumers to a new socio-economic and cultural reality - to the New Social World (Ganskiy, 2015). This is facilitated by the speed and easy transition to the NSW, social networks provide absolutely free access, despite the huge costs of maintaining accounts, their performance, and, most importantly, storing a huge amount of information, including photo and video content. The American budget took on the burden of building, operating, and storing petabytes of information waste that fills social networks every day, primarily Instagram, Facebook, TikTok, Twitter (Romanov, Shabaev, 2020). It is unlikely that this is done for reasons of "information ecology". This is the potential opportunity to manipulate every consumer, every member of social networks. These manipulations can appear in different fields of life. Accordingly, it is as much an incentive for its preservation 
as an obvious political valuation. The political resonance of new communication channels is obvious as "fundamentally new ... ways of communication interaction between individuals, institutions, and authorities", leading to the fact that politics nowadays "is increasingly moving from offline (real area) to online (virtual area), political communication adapts to the requirements and principles of the Network" (Bronnikov, 2011: 3).

The essence of the ongoing transformations of the political space was clearly expressed not by a professional political scientist, but by a well-known poet: "thanks to the Internet, which is represented by its apologists as a "space of freedom" not controlled by the state, a field of free criticism and socio-political protest, the energy of this protest is taken into virtual space, where you can speak and write, really, whatever you want. But remaining in real life as a slave, unable to change anything. The political essence of the Internet is a scarecrow of freedom" (Bobrov, 2009: 6).

The conclusion is unambiguous: social networks have become a powerful tool for influential political power (Dean, 2017), "a fertile environment for massive processing of public consciousness and large-scale political manipulation", which allows us to recognize that "social cyberspace" and "virtual communication networks are beginning to perform a political function and, in fact, become political networks" (Mikhailenok, Malysheva, 2019: 86). The main characteristics of the New Social World are: full, permanent, and free access to social networks and to thematic services, e-commerce, grocery, medical services, free access to the most diverse (video, audio, text, games, films, etc.) entertainment content and also to educational and other types of content. In reality, social networks initially opposed themselves to the traditional society of the 20th century and in essence are aimed at destroying it and creating fundamentally new social relations. In this regard, one cannot but agree that "according to many Western researchers, virtual communities should be perceived as quite real social formations" (Bataeva, 2011: 91).

The possible anti-religious nature of the New social world is also very important to study. Monitoring social networks gives the impression that neither Christianity, nor Islam, nor Buddhism, nor Judaism can resist the New social world. Only "closed" marginal religious groups remain outside the influence of the NSM, prohibiting their members from approaching the computer, in particular, and the Internet in general. Regular public protests of believers on this topic are presented by the new social world's media as manifestations of obscurantism, religious fanaticism, dogmatism, bigotry and intolerance, and "civilizational backwardness". World "public opinion" is moving away from the question of what actually caused new religious wars in Asia and the rise of "Islamic extremism".

An effective mechanism for drawing all new adherents into the NSM is the unlimited possibilities of a person's "self-realization". It is leisure, entertainment, in the language of social networks - world of entertainment. Any user is provided with unlimited and free gaming opportunities, countless options for photo, video, film viewing, and music. The numerous teenagers constantly scrolling with their fingers through billions of videos (small video clips) on TikTok around the world. Billions of people browse billions of short videos 
with questionable content per day. In fact, social networks claim all of a person's free time and absorb it, without compensating in any way and narrow the possibility of people's true self-realization which is possible only in the form of influencing reality (Afanasov, 2020). "Creativity is changing the world". Creativity is the internal structure of the unique human personality. But even bloggers, whose revelations are listened to by millions of users act according to the laws prescribed by social networks. Millions of people within the NSW have the illusion of self-realization. In fact, a person becomes addicted to the new social world, acquires habits already on the Internet, and loses their unique individuality.

Another cornerstone of the NSW is limitless information and direct communication. Previously the creation, reception, and analysis of the information took place in personal communication between people and transmitted through traditional media. Now social networks offer any type and volume of information that exceed the capabilities of human perception. The NSW is a bottomless source of any kind of information. Direct communication between users allows information to be instantly disseminated to millions of users around the world. Even Google lags behind social media in terms of the number of topics discussed. There is no longer the need to look for information of interest. There are no spiritual, moral, or any other barriers on the topic of inquiries: what members want is what members ask - and get everything, including what members don't want. This circumstance allows calling what is happening "information flood".

Another important characteristic of the NSW is an extremely high level of trust in social networks (Ilyinykh, 2021), especially among young people who are confident in the reliability of social networks (Chernov, Abramov, 2019), such an infinite "freedom" of obtaining information actually leads to dire consequences on the destruction of the internal integrity of the individual, not to mention social pathologies, methods of self-healing and "scientific revelations" that have nothing in common with science and are not verified in social practice.

The most provocative factor of involvement in NSW is the illusion of successful work and easy enrichment. This myth is deliberately imposed on young social groups in order to reduce social tension in a society where real "social lifts" for the bulk of young people are practically absent. In addition, it became a psychological justification for shifting the center of gravity of activity - or rather, inactivity - to social networks. The number of representatives of new professions - bloggers, influencers, digital producers, etc. threatens to become comparable to the number of users. The effectiveness of some of them is undeniable: the huge audiences of social networks attract advertisers. Globally, there has already been a strategic shift in favor of the Internet - all developed markets spend more on online advertising than on traditional media. In Russia, this turning point also took place in 2019, when, according to the Association of Communication Agencies of Russia, Internet advertising spending exceeded television advertising revenue (AKAR, 2021). Approximately, about 15 million out of 120 million Russians are trying to build a business on the network, developing their own accounts to increase the number of subscribers, expecting subsequent capitalization. However, only 5\% of them become bloggers and influencers with a small income. And only some of them reach the level of permanent income of more than $\$ 200$ per month. As a result, only about 15 thousand bloggers and influencers 
earn more than $\$ 1,300$ a month online, but, as a rule, their accounts are supported by advertising agencies and production centers. To create a truly profitable business of your own on the network requires significant investments that ordinary users simply do not have.

Another important characteristic of the New Social World is a powerful sanctions apparatus, which is applied to journalists, bloggers, publicists, to everyone who is critical and negative about social networks. The "invisible hand" of the New Social World is rapidly turning on sanctions (Knyazeva, 2013). In the beginning, the task of these sanctions is to edit the "wrong" materials as much as possible in the "right direction", and if this fails, the "invisible hand" of the new social justice will ensure you a quick and irreversible removal of the material (Taranukha, 2018). Of great importance for understanding the mechanisms of the activity of social networks are the sanctions against all "wrong-minded", up to the disconnection of the "guilty" from social networks. Suffice it to give an example, when the President of the United States Donald Trump was disconnected from social networks at the same time as thousands of his supporters. The attempts of individual citizens to recover in the network are quickly suppressed because of total control. In fact, "today we have reached such a level of immersion in social networks and services that we ourselves, of our own free will, become their voluntary and permanent hostages" (Galiullin, 2015). Rather rigid rules are constantly expanding and acquiring an increasingly systemic character, which, in fact, are turning into a new set of laws by which millions of people live, although they are developed not by the legislative authorities, but by the subjects of the information market. This set of laws is called "User Agreement" or "Terms of Use". This is a large and serious data set, so a comparison with a body of laws is quite appropriate.

Another important phenomenon of the development of the New Social World is the unhindered entry of any person into it, without explaining the "rules of the game", but in fact without explaining the rules of the new life. Never before has humanity faced such a situation. $95 \%$ of users of social networks have not read the User Agreements, an integral part of which are tough sanctions for any violations initially recognized as malicious (Perzanowski, Schultz, 2019). Thus, it can be stated that social networks rigidly suppress dissent, a critical attitude towards themselves and their rules, instantly block negative information, and have a rigid mechanism for censoring materials posted on the network. Social networks have the broadest opportunities for their own promotion online and offline and spend huge amounts of money on expanding their audience, as well as creating their own absolutely positive image in the world. They analyze constantly updated information for each user, create groups according to the same characteristics, create a dossier for each user and for each user group, archive and store all information from the moment they start working. Everything that was on the social network remains forever, even what was posted for a second and immediately erased. 


\section{CONCLUSION}

New types of sociocultural and media communications, including social networks, messengers, video conferencing programs, search resources, other online communicators, music and other thematic services, free online games in mobile and desktop, and other entertainment have long enough exerted for millions of people a strong and growing influence in different countries, however, the majority of citizens continued to live within national borders and traditional societies, where, it would seem, there is a separate place for "online".

However, very quickly, thanks to technical and technological progress, as well as the short-sighted position of many states, new types of sociocultural and media communications easily crossed national and intra-social boundaries, making the absolute majority of the world's inhabitants their users. Mark Zuckerberg's Meta Platforms alone controls nearly 11 billion accounts worldwide. The coronavirus pandemic has spurred and intensified this process. Even those marginal groups that had previously resisted entering the Internet in every possible way were forced to enter the new social space. Without this, now it is impossible to issue a pass, not to receive a pension or benefits, not to issue a QR code, certificates and documents, not to order food and medicines. And you don't have to leave the apartment at all ... The new social space, which we call the New Social World, has the following important characteristics: voluntary and free participation of the majority of users, who are provided with the entire set of services necessary for a full-fledged social life, complete obedience to clear and strict norms and rules described in user agreements, total online control and online monitoring of the activities of NSW members, production of its own hierarchy of sociocultural values and the formation of new life meanings, full-fledged influence on all forms of life of members, promotion of their own supranational values while maintaining direct communication and exchange of information of all members, creation of a single ecosystem that can provide members with access to goods, services, and wide entertainment.

In addition, the NSW is characterized by a tough sanctions apparatus, a powerful system of its own promotion, and the ability to self-analyze. Given the scale of the New Social World and its powerful expansion to all countries, social strata, and new generations, it becomes obvious that the main problem that humanity faces in the 21st century is to preserve under its massive onslaught the traditional human world based on cultural values developed by different peoples over the millennia, that allowed people to reach the heights of modern civilization. For European countries, the New Social World and its impact on all spheres of society are becoming a national security problem (El'iakov, 2013). It is already impossible and senseless to simply "fight" the NSW. Now we can only try to direct the unprecedented potential of its information and technological power in a constructive direction, try to make this phenomenon a "graft" of national and cultural identity in order to preserve the spiritual and moral values of Europe. It is in this direction that it is necessary to think and act for representatives of state institutions created to protect state sovereignty. 
FUNDING: The authors did not receive any external funding.

CONFLICT OF INTEREST: The authors declare no conflict of interest.

\section{REFERENCES}

1. Afanasov, N. B., (2020) Paradoksy svobodnogo vremeni v cifrovuju jepohu. Voprosy filosofii, no.10, pp. 57-65. DOI: https://doi.org/10.21146/0042-8744-2020-10-57-65 Available at: https://www.elibrary.ru/item.asp?id=44158976

2. AKAR (2021) Objemy rynka reklamy [Advertising Market Volumes]. Available at: https://www.akarussia.ru/knowledge/market size

3. Bailey, R., Purkayasha, P. U.S. Control of the Internet. Monthly Review, Vol. 66, no. 3, Available at: https://monthlyreview.org/2014/07/01/u-s-control-of-the-internet

4. Bataeva, E. V., (2011) Jetnometodologicheskij analiz onlajn-kommunikacii: krizisnyj jeksperiment $\mathrm{v}$ chatah. Sociologicheskie issledovanija, no.12, pp.88-98. Available at: https://www.elibrary.ru/item.asp?id=17239233

5. Bobrov, A., (2009) O sile i slabosti Interneta. Sovetskaja Rossija, no. 24 (132410), 6 p. Available at: https://sovross.ru/articles/295/5026

6. Bronnikov, I. A., (2011) Osobennosti seti Internet kak form1y politicheskoj kommunikacii. Avtoref. diss. ... kand. polit. nauk., Moscow, 25 p. Available at:

https://www.elibrary.ru/item.asp?id=19365827

7. Chernov, A. S. and Abramov, A. P., (2019) Perspektivnye napravlenija formirovanija vzaimnogo doverija molodezhi i vlasti. Izvestija Jugo-Zapadnogo gosudarstvennogo universiteta, Serija: Jekonomika. Sociologija, Menedzhment, Vol. 9, no.3, pp. 168-173. Available at: https://elibrary.ru/item.asp?id=39289891

8. Delicyn, L. L., (2010) Skoro li pol'zovatel' Interneta stanet pohozh na srednego rossijanina? Onlajn issledovanija v Rossii 2.0, pod redakciei A. V. Shashkina, I. F. Devjatko, S. G. Davydova, Moscow, Publishing House «Severo-Vostok», pp. 31-42 Available at:

https://www.elibrary.ru/item.asp?id=19668744

9. Dean, D., (2017) Communicative capitalism: from disagreement to separation. Communications. Media. Design, Vol. 2, no. 3, pp. 152-165. URL: https://www.elibrary.ru/item.asp?id=32619264

10. Efimova, G. Z. and Zjuban, E. V. (2016) Vlijanie social'nyh setej na lichnost'. Mir nauki. Pedagogika i psihologija, Vol. 4, no. 5. pp. 1-27. Available at: https://www.elibrary.ru/item.asp?id=30096152

11. El'iakov, A. D., (2013) Problemy informacionnoj bezopasnosti v ispol'zovanii jelektronnyh komp'juternyh tehnologij. Sociologicheskie issledovanija, no.10, pp. 120-129. Available at: https://www.elibrary.ru/item.asp?id=20366252 
12. Galiullin, M. Je., (2015) Ispol'zovanie social'nyh setej dlja ocenki urovnja obespokoennosti naselenija voprosami bezopasnosti zhiznedejatel'nosti. Tehnologii grazhdanskoj bezopasnosti, Vol.12, no. 2 (44), pp. 70-73. Available at: https://www.elibrary.ru/item.asp?id=23606459

13. Ganskiy, P. N., (2015) Internet-prostranstvo kak osobaja kommunikacionnaja sreda i ego vlijanie na sovremennye obshhestva. Teorija i praktika obshhestvennogo razvitija, no.17, pp. 118-121. Available at: https://www.elibrary.ru/item.asp?id=24168824

14. Hootsuite, W. A. S. (2021). Digital 2021: Global Overview Report. DataReportal-Global Digital Insights. Available at: https://datareportal.com/reports/digital-2021-global-overview-report

15. Ilyinykh, S. A., (2021) Internet kak istochnik informacii: vzgljad skvoz' prizmu doverija. Vestnik Tomskogo gosudarstvennogo universiteta, no. 467, pp.124-132. DOI:

10.17223/15617793/467/16. Available at: https://www.elibrary.ru/item.asp?id=46662302

16. Knjazeva, E. N., (2013) Social'naja slozhnost': samoorganizacija, trendy, innovacii. Obshhestvo: filosofija, istorija, kul'tura, no. 1, pp. 20-28. Available at: https://www.elibrary.ru/item.asp?id=18852428

17. Lokosov, V. V., (2020) Demograficheskoe razvitie Rossii: dinamika i social'no-jekonomicheskie riski. Vestnik Rossijskoj akademii nauk., Vol. 90, no. 3, pp. 251-258.

DOI: https://doi.org/10.31857/S086958732003010X Available at: https://www.elibrary.ru/item.asp?id=42578336

18. Lyfenko, N. D., (2014) Virtual'nye pol'zovateli v social'nyh setjah: mify i real'nost'. Voprosy kiberbezopasnosti, no. 5 (8), pp. 17-20. Available at: https://www.elibrary.ru/item.asp?id=22872256

19. Mediascope. (2021) Auditoriya Interneta v Rossii v 2020 godu [Internet audience in Russia in 2021] Mediascope. Available at: https://mediascope.net/news/1250827/

20. Mihajlenok, O. M. and Malysheva, G. A., (2019) Politicheskie jeffekty social'nyh setej v Rossii. Sociologicheskie issledovanija, no. 2, pp. 78-87. DOI: https://doi.org/10.31857/S013216250004012-6 Available at: https://www.elibrary.ru/item.asp?id=37156868

21. Morozov, A. V. (2019) Ostorozhno, metamodern: sovremennost' kak zontik i majatnik. Galactica Media: Journal of Media Studies, no. 3, pp. 238-249. DOI: https://doi.org/10.24411/2658-77342019-10032 URL: https://www.elibrary.ru/item.asp?id=41311889

22. Orwell, G., (2016) 1984 / transl. from English by V. P. Golysheva. Moscow, AST, 320 p. ISBN: 978-5-17-103595-2

23. Otreshko, N. (2009) Kartiny social'nogo mira: koncepty obshhestva i subjekty dejstvija v sociologicheskoj teorii. Sociologija: teorii, metody, marketing, no.1, pp. 127-137. Available at: https://www.elibrary.ru/item.asp?id=16342885

24. Pastukhov, A. G. (2012) Infotejnment i jedutejment: cifrovye media protiv bumazhnyh? Filologija i chelovek, no. 4, pp. 1-5. Available at: https:/elibrary.ru/item.asp?id=18083696 
25. Perzanowski, A. and Schultz, J. (2019) The End of Ownership: personal property in the digital economy / transl. from English by E. Lebedeva. Moscow, Publishing House DELO, RANHiGS, 352 p. DOI: https://doi.org/10.2966/scrip.140217.401

26. Petukhov, V. V. and Barash, R. Je., (2012) Hotjat li rossijane demokratiju, i, esli hotjat, to kakuju? Monitoring obshhestvennogo mnenija: jekonomicheskie i social'nye peremeny, no. 5 (111), pp. 46-58. Available at: https://www.elibrary.ru/item.asp?id=18113712

27. Ponarina N. N., (2011) Vozdejstvie globalizacii na kommunikacii. Teorija i praktika obshhestvennogo razvitija, no. 3, pp. 36-38. Available at: https://www.elibrary.ru/item.asp?id=17748459

28. Romanov, A. A. and Shabaev, V. V., (2020) «Fake news» v social'nyh setjah, blogah i messendzherah kak ugroza informacionnoj bezopasnosti, Jurist - Pravoved magazine, no. 1(92), pp. 16-20. Available at: https://www.elibrary.ru/item.asp?id=42718529

29. Sergeeva, Ju. (2021) Vsja statistika interneta i socsetej na 2021 god [online] WebCanape. Available at: https://www.web-canape.ru/business/vsya-statistika-interneta-i-socsetej-na-2021god-cifry-i-trendy-v-mire-i-v-rossii/

30. SZTOMPKA, Piotr. (2017) Spravedlivost'. Monitoring obshhestvennogo mnenija: Jekonomicheskie i social'nye peremeny, no. 6, pp. 381-399. Available at: https://www.elibrary.ru/item.asp?id=32290154 DOI: https://doi.org/10.14515/monitoring.201 7.6 .21

31. Silaeva, V. L. (2008) Internet kak social'nyj fenomen. Sociologicheskie issledovanija, no. 11, pp. 101-107. Available at: https://www.elibrary.ru/item.asp?id=11563048

32. Taranukha, Ju. V. (2018) «Nevidimaja ruka» Adama Smita. Obshhestvennye nauki i sovremennost', no. 6, pp. 162-173. DOI: https://doi.org/10.31857/S0869049900027585 Available at: https://www.elibrary.ru/item.asp?id=36686105

33. Vasilyev, N.V. and Komissarov, S.N., (2021) Socialnye seti. Formirovanie novogo socialnogo mira. Gumanitariy Yuga Rossii, Vol. 11, no. 4, pp. 43-61. DOI: https://doi.org/10.18522/22278656.2021 .4 .3

34. Vladimirova, T. V., (2011) Setevye kommunikacii kak istochnik informacionnyh ugroz. Sociologicheskie issledovanija, no. 5, pp. 123-129. Available at: https://www.elibrary.ru/item.asp?id=16379967

35. Voronkin, A. S., (2014). Social'nye seti: jevoljucija, struktura, analiz. Obrazovatel'nye tehnologii i obshhestvo, Vol. 17. pp. 650-675. Available at: https://www.elibrary.ru/item.asp?id=22477978

36. Zuboff, S. (2019) The Age of Surveillance Capitalism. New York, Public Affairs, 691 p. DOI:10.12957/rmi.2021.55150 